\title{
SWEDISH PRIMARY AND PREPRIMARY STUDENT TEACHERS' VIEWS OF USING DIGITAL TOOLS IN PREPRIMARY MATHEMATICS EDUCATION
}

Timo TOSSAVAINEN *, Lulea University of Technology, Sweden

Maria JOHANSSON, Lulea University of Technology, Sweden

Ewa-Charlotte FAARINEN, Lulea University of Technology, Sweden

Anna KLISINSKA, Lulea University of Technology, Sweden

Anne TOSSAVAINEN, Lulea University of Technology, Sweden

Přijato: 19. 6. 2018 / Akceptováno: 25. 8. 2018

Typ článku: Teoretická studie

DOI: $10.5507 /$ jtie.2018.007

Abstract: Our study surveys Swedish primary and preprimary student teachers' $(n=94)$ views of content and methods of mathematics education in preschool and, especially, of using digital tools in preprimary mathematics education. The views related to digital tools turned out to be clearly positive in general. Students who are strongly for using digital tools are also more sure in saying that mathematics education in preschool should be fun. However, they agree less with the claims such as mathematics lessons should be structured, or that the responsibility for the mathematics education of small children belongs mainly to their parents. Those students who were quite strongly for using digital tools agreed less with the claim that mathematics is one of the most important areas of preprimary education. The willingness to take responsibility for children's mathematical education from the parents was the most significant single factor to explain the participants' opinions about using digital tools.

Key words: a digital tool, ICT, mathematics education, preprimary, primary, view.

\section{POHLED ŠVÉDSKÝCH STUDENTŮ UČITELSTVÍ NA VYUŽITÍ DIGITÁLNIICH NÁSTROJŮ V PREPRIMÁRNÍM MATEMATICKÉM VZDĚLÁVÁNí}

Abstrakt: Naše studie se zaměruje na výzkum názorů studentů preprimární pedagogiky (počet = 94) na obsahové a metodické pojetí matematického vzdělávání na předškolní úrovni, predevším na využití digitálnich nástrojü. Názory týkajicí se digitálních nástrojů se ukázaly jako všeobecně pozitivní. Studenti, kteři ve větši míre využivají digitální nástroje tvrdi, že matematické vzděláváni realizované v předškolním věku by mělo být zábavné. Nicméně méně souhlasí s tvrzením, že matematické lekce by měly být systematicky strukturovány 
nebo, že odpovédnost za matematické vzdělávání malých dětí nesou hlavně rodiče. Tito studenti rovněž méně souhlasili s tvrzením, že matematika je jednou $z$ nejdůležitějšich oblastí predškolního vzdělávání. Ochota přvevit odpovédnost za matematické vzdělávání od rodičù dètí byla nejvíce signifikantním faktorem $k$ vysvětleni názorů souvisejicích s využiváním digitálních nástrojü.

Klíčová slova: digitální nástroj, ICT, matematické vzdělávání, preprimární vzdělávání, primární vzdělávání.

*Autor pro korespondenci: timo.tossavainen@1tu.se

\section{Introduction}

The discussion about the goals and means of preprimary mathematics education is continuous and has raised different opinions both in Sweden and internationally (e.g., Doverburg \& Samuelsson, 2011; Palmer \& Björklund, 2016; Cross, Woods \& Schweingruber, 2009; Lee \& Ginsburg, 2007). One of the central questions has been whether computers and other digital tools should be used already in preschool and, if so, in what ways (e.g. Yellend, 2005). According to Wang and Hoot (2006), most teachers are moving away from the question of if it is appropriate with digital tools in early childhood education, to rather ask how digital tools can be used effectively. Ten years later, a large survey made in Finland by Mertala (2017) suggests that about 80 percent of the early childhood teachers have a positive attitude toward using ICT (= Information and communication technology) with children.

According to Wang and Hoot (2006), most research supports the benefits of ICT for young children's social and cognitive development. Also Sarama and Clements (2009) found in their literature review that the use of computers had more advantages for children in developing mathematical thinking than physical objects: "compared with their physical counterparts, computer representations may be more manageable, flexible, extensible, and 'clean' (i.e., free of potentially distracting features)" (p. 147). On the other hand, although young learners often have a positive view of using computers in education, they also admit that use of computers has not necessarily helped them to achieve improved learning results (e.g. Tossavainen \& Hirsto, 2018).

We focus in this article on primary and preprimary student teachers' views on the use of digital tools. The motivation for this study is the fact that the views that teacher students (and teachers) have affect the way they plan their teaching and what kind of materials they use, cf. Wilson \& Cooney (2002). In Sweden, more than 90 percent of children of age 25 attend preschool even though it is not compulsory. This means that most children in Sweden are in an environment where teaching and learning is guided by a preschool teacher with a curriculum. However, the Swedish preschool curriculum does not address any direct goals for the children to learn but states what preschool teachers and preschool in whole should do in order to provide children possibilities to develop certain skills. For example, preschool teachers are urged to work for that every child develops his/her ability to use mathematics in problem solving and to reflect and communicate using also mathematical concepts (Skolverket, 2016).

So, in this article, we talk about preprimary education meaning the education given at preschool for children at the age of $2-5$. Further, a digital tool refers to a computer, a tablet 
computer, a smart phone or any similar digital product with applications or resources that can be used for educational purposes in preschool. For example, a movie maker application on iPad is a digital tool since a teacher and children can use it for demonstrating a concept or a process they have studied. For a more thorough discussion on the notion of a digital tool, we refer to MIT (2018).

\section{Theoretical framework}

Our study is rooted to two theoretical perspectives. First, Grigutch, Raatz, and Törner (1998) have surveyed mathematics teachers' views of what mathematics is, and basing on that they defined four different aspects to depict the nature of mathematics. These are 1) formalism - mathematics as an exact, formal, and logical science, 2) scheme - mathematics as a collection of rules and formulas, 3) process - mathematics as a science that mainly consist of problem solving processes and, 4) application - mathematics as a science which is relevant for society and life. The last two are called static beliefs and the first two dynamic beliefs. In static beliefs mathematics exists and therefore should be discovered, whereas dynamic beliefs stress that mathematics is created by humans (Tossavainen et al., 2017).

Secondly, we survey the participants' views that concern preschool teachers' pedagogical content knowledge in mathematics (Hill, Ball \& Schilling, 2008), i.e., their knowledge about that how to formulate and represent the mathematical content in teaching so that it becomes comprehensible. Pedagogical content knowledge deals also with understanding what prerequisities learners have for the adoption of a specific mathematical content to be learnt.

The previous research has obviously considered preschool teachers' and teacher educators' views of what preschool mathematical education is or should be but there is not a unanimous answer to this question. For example, Palmer and Björklund (2016) provide an overview of eight Nordic articles which demonstrate a large diversity of aims and goals within preschool mathematics. The study of Doverborg and Samuelson (2011) show that there is a dramatic development in the mathematical skills of children between the age of one and three years. This sets high demands on preschool teachers' mathematical skills in supporting children's learning, e.g., how children's everyday experiences can be interpreted mathematically. Lee and Ginsburg (2007) have studied pre-kindergarten teachers' beliefs of what appropriate mathematics education for four-year-olds is. According to their study, teachers sense the pressure of current educational trends with increased academic demands. They acknowledge, e.g., the importance of teaching simple arithmetic in playful ways.

\section{Research questions}

Our research questions are as follows.

(i) Are Swedish primary and preprimary student teachers for or against using digital tools in preprimary mathematics education?

(ii) How variation in the respondents' answers concerning the use of digital tools is reflected on their views of the content, goals, and teaching methods in preprimary mathematics education?

(iii) How do age, experience from work or other similar factors explain the participants' views of using digital tools in preprimary mathematics education? 


\section{Method}

Our data were collected using a questionnaire based on altogether eighteen claims with the seven level Likert-type scale so that $1=$ "very strongly disagree" and $7=$ "very strongly agree". The claims were designed to measure the respondents' views of the nature of mathematics and their views of the sufficiency and quality of preschool teachers' pedagogical content knowledge in mathematics, see Tables 1-2 below. In the introductory text, all items were explicitly contextualized in preschool. The questionnaire contained also two other sections surveying, for example, the participants' educational background.

The study was implemented at a Swedish university with three groups of students who were in the beginning of their university studies and had not taken any mathematics courses in their university program. The first group consists of 27 preprimary student teachers, the second one of 42 lower primary (Swedish grades F-3) student teachers and the third group of 25 upper primary (Swedish grades 4-6) student teachers. The participants answered the questionnaire during an ordinary lesson. Answering the questionnaire was not required, but all attending students took part in the research and, so, the total answer rate was $100 \%$.

The participants' responses to the Likert scales were analysed using the Student's ttests and Oneway analysis of variance (Oneway ANOVA), and by performing Pearson correlation analyses.

\section{Results}

We answer our research questions in two phases. First, we consider the participants' agreement/disagreement with the claim (no. 4.9 in the questionnaire, cf. Table 2) "Digital tools do not belong to teaching mathematics to young children". Thereafter, we divide the participants into two groups: $\mathrm{A}=$ those who are strongly for using digital tools $\left(N_{A}=42\right)$; $\mathrm{B}=$ other participants $\left(N_{B}=52\right)$, and we investigate how these groups have responded to the seventeen other claims. This will produce an answer to the second research question. The answer to the last question is based on the correlation analyses of the included variables.

\begin{tabular}{|c|c|c|c|c|}
\hline Mean & Std. deviation & Min & Max & N \\
\hline 2.06 & 1.41 & 1 & 7 & 93 \\
\hline
\end{tabular}

Table 1: The descriptive measures of Item 4.9

The descriptive measures of students' responses to Item 4.9 are given in Table 1. The mean value 2.06 differs highly significantly from the expected value $4.00(\mathrm{t}(92)=-13.21$, $\mathrm{p}<.001$ ), so, the result can be generalized to stand for the whole population. On the other hand, the Oneway ANOVA test did not reveal any differences between the groups of preprimary, lower primary and upper primary students. In other words, Table 1 shows that the Swedish preprimary and primary student teachers have a clearly positive view of using digital tools in preprimary mathematics education. On the other hand, there are also opposite views. We shall discuss the novelty value of these findings in more details in the last section.

Table 2 summarizes groupwise the participants' responses to the other claims. It shows that the participants see counting with small numbers as being more central to preprimary mathematics education than communication with correct terminology (Items 4.1-2). The difference between means of these variables (5.31 and 4.55) is highly significant in the paired-samples t-test: $(\mathrm{t}(93)=3.92, \mathrm{p}<.001)$. Having fun with mathematics is very important in their view (Item 4.3), the learning of the important role of mathematics in modern 
society not that important (Item 4.4). However, that children learn to use mathematics in solving everyday problems and that they recognize creativity and discovering new things as essential parts of mathematics are quite important goal for the participants (Items 4.56). However, every child does not have to learn to solve mathematical problems on his/her own already in preschool (Item 4.11). This issue however divided opinions, the standard deviation for this variable is 1.84 which is the second highest among all variables. Similarly, the respondents do not show a clear opinion whether mathematics is one of the most important areas of early childhood education or not (Item 4.14).

In the framework of four aspects defined by Grigutsch, Raatz, and Törner (1998), Table 2 indicates that the participants have more static than dynamic beliefs about the nature of mathematics. Items which refer to process-related or application-related orientations have higher means than those which refer to formalism-related or schemerelated orientations. In other words, the students tend to think that mathematics is an already existing content that has to be delivered to learners than knowledge and skills that learners themselves should construct and develop.

What comes to the participants' views of mathematical knowledge for teaching, the respondents do not support the idea of organizing preprimary mathematics education as clearly structured lessons but strongly appreciate playful and informal methods (Items 4.8 and 4.12). The participants' views related to discussing problems for which a teacher does not know an exact answer (Item 4.7) varied to a quite high degree, the standard deviation for the whole sample is 1.89 being the highest among all variables. However, they modestly agree with the claim that preprimary teachers are trained well enough to teach mathematics (Items 4.13 and 4.17) and they are quite neutral to the question, should preprimary teachers be given detailed instructions what to teach in mathematics or not (Item 4.10). Nevertheless, they are not very willing to leave the responsibility of children's mathematical education to the parents but see that it must start already in preschool and as a subject on its own (Items 4.15-16 and 4.18).

\begin{tabular}{|l|c|c|c|c|}
\hline \multicolumn{1}{|c|}{ Item } & $\overline{\boldsymbol{x}}_{\boldsymbol{A}}$ & $\overline{\boldsymbol{x}}_{\boldsymbol{B}}$ & $\boldsymbol{\delta}_{\boldsymbol{A}}$ & $\boldsymbol{\delta}_{\boldsymbol{B}}$ \\
\hline $\begin{array}{l}\text { 4.1 Teaching should focus on learning to count with } \\
\text { small numbers (1-10). }\end{array}$ & 5.31 & 5.31 & 1.57 & 1.26 \\
\hline $\begin{array}{l}\text { 4.2. Children should learn to communicate their } \\
\text { mathematical thoughts using correct terminology. }\end{array}$ & 4.62 & 4.50 & 1.53 & 1.43 \\
\hline $\begin{array}{l}\text { 4.3. The most important thing is that children have fun } \\
\text { with mathematics. }\end{array}$ & $\mathbf{6 . 9 0}$ & $\mathbf{6 . 5 4}$ & .30 & .86 \\
\hline $\begin{array}{l}\text { 4.4. Children should learn that mathematics is important } \\
\text { for maintaining and developing the modern } \\
\text { technological society. }\end{array}$ & 4.64 & 4.49 & 1.53 & 1.64 \\
\hline $\begin{array}{l}\text { 4.5. Children should learn to use mathematics in solving } \\
\text { everyday problems. }\end{array}$ & 5.95 & 5.60 & .96 & 1.29 \\
\hline $\begin{array}{l}\text { 4.6. Children should learn to know that mathematics } \\
\text { requires creativity and is about discovering new things. }\end{array}$ & 5.95 & 5.63 & 1.10 & .98 \\
\hline $\begin{array}{l}\text { 4.7. Teaching of mathematics should not contain such } \\
\text { problems that teacher cannot give an exact answer. }\end{array}$ & 4.32 & 4.65 & 2.15 & 1.66 \\
\hline $\begin{array}{l}\text { 4.8. It is a good idea to organize mathematical education } \\
\text { as clearly structured lessons. }\end{array}$ & $\mathbf{2 . 9 5}$ & $\mathbf{3 . 7 3}$ & 1.99 & 1.66 \\
\hline $\begin{array}{l}\text { 4.10. Preschool teachers should be given detailed } \\
\text { instructions what they should teach in mathematics. }\end{array}$ & 4.43 & 4.61 & 1.52 & 1.27 \\
\hline
\end{tabular}




\begin{tabular}{|l|c|c|c|c|}
\hline $\begin{array}{l}\text { 4.11 Every child should learn to solve mathematical } \\
\text { tasks on his/her own. }\end{array}$ & 3.55 & 3.49 & 2.05 & 1.68 \\
\hline $\begin{array}{l}\text { 4.12. Informal and playful teaching methods are more } \\
\text { suitable than those based on lecturing and using } \\
\text { textbooks. }\end{array}$ & 6.48 & 6.49 & .99 & .72 \\
\hline $\begin{array}{l}\text { 4.13. Preschool teachers are trained well enough to teach } \\
\text { mathematics. }\end{array}$ & 4.85 & 4.94 & 1.20 & 1.20 \\
\hline $\begin{array}{l}\text { 4.14. Mathematics is one of the most important areas of } \\
\text { early childhood education. }\end{array}$ & 4.07 & 4.39 & 1.50 & 1.36 \\
\hline $\begin{array}{l}\text { 4.15. It is first and foremost parents' task to control that } \\
\text { children learn those mathematical skills that they need in } \\
\text { school. }\end{array}$ & $\mathbf{2 . 4 0}$ & $\mathbf{2 . 9 8}$ & 1.23 & 1.44 \\
\hline $\begin{array}{l}\text { 4.16. It is enough if mathematical education is contained } \\
\text { in teaching of mother tongue and other subjects. }\end{array}$ & 2.60 & 2.86 & 1.55 & 1.31 \\
\hline $\begin{array}{l}4.17 . \text { There should be specially trained mathematics } \\
\text { teachers in preschool. }\end{array}$ & 3.50 & 3.22 & 1.93 & 1.59 \\
\hline $\begin{array}{l}4.18 . \text { Teaching mathematics does not belong to } \\
\text { preschool but should start at school. }\end{array}$ & 2.05 & 2.43 & 1.36 & 1.40 \\
\hline
\end{tabular}

Table 2: The summary of the participants' responses

Table 2 shows also in which items the groups differ from one another in a statistically significant way. These items are highlighted with the bold face font and they are Item 4.3 $(\mathrm{t}(62)=-2.80, \mathrm{p}<0.01)$; Item $4.8(\mathrm{t}(90)=2.04, \mathrm{p}<0.05)$; and Item $4.15((\mathrm{t}(91)=2.05, \mathrm{p}<0.05)$. In other words, those students who strongly support using digital tools in preprimary mathematics education emphasize more having fun, are more against organizing mathematics education in preschool as structured lessons, and are more willing to take responsibility for that children learn those mathematical skills that are needed in school.

If we modify the definition of the groups $\mathrm{A}$ and $\mathrm{B}$ so that the cut point is three instead of two, then there is a significant difference also in Item $4.14\left(\mathrm{t}(91)=2.19, \mathrm{p}<0.05, \bar{x}_{A}=\right.$ 4.07, $\bar{x}_{B}=4.82$ ). In other words, those students who are strongly or rather strongly for using digital tools in preprimary mathematics education see mathematics being less important area of early childhood education as other students.

We conclude this section by reporting from the Pearson correlation analyses of Items 4.1-18 and variables describing the participants themselves and their educational background. The analyses revealed that the willingness to take responsibility of children's mathematical education from the parents was the only variable having a statistically significant correlation with Item 4.9, i.e., the participants' views of using digital tools in preprimary mathematics education $(r=.31, \mathrm{p}<.01)$. As we see from the correlation coefficient, the size of this effect is at a medium level.

Surprisingly, age, experience from working in primary or preprimary education or from studying at the university level did not correlate with Item 4.9. Neither is Item 4.9 dependent on gender or the grade in mathematics. The correlation between Items 4.9 and 4.14 (see Table 2) was however almost statistically significant $(r=.20, \mathrm{p}=.052)$. This indicates the same conclusion as already mentioned above: the more favourable the students are for using digital tools in preprimary mathematics education, in their view, the less central role mathematics have in preprimary education. However, the effect size is now small.

To sum up, using digital tools in preprimary mathematics education seems to be widely accepted among the Swedish students. However, there is some variation of views in this 
issue and, in our data, the variation is primarily related to the variation of opinions on that to what degree it is parents' task to control that their children develop skills and knowledge needed in school.

The correlation analyses revealed a few other interesting relations, too. For example, the correlation between age and Item 4.13 was statistically significant $(r=-.25, \mathrm{p}<.05)$ telling that the older the participants are, the less they agree that preschool teachers are well enough educated in mathematics. This opinion is related also to the amount of experience from having worked as teacher. The correlation between these variables is also statistically significant $(r=-.23, \mathrm{p}<.05)$.

\section{Discussion}

As mentioned in the introduction, the student teachers' views of the nature and importance of mathematics have an effect on that how they will plan their teaching and what kinds of materials they will use in their profession. In this sense, a remarkable finding in this study is that prospective primary and preprimary teachers indeed have a quite strongly positive relation to using digital tools in preprimary mathematics education. As Wang \& Hoot (2006), Mertala (2017), and our own experience from preprimary and primary teacher education show, this view has not always been self-evident. Therefore, this change should be acknowledged in early childhood teacher education so that upcoming teachers can better develop those skills and knowledge that are needed for a successful ICT-based education in mathematics. The study of Tossavainen and Hirsto (2018) shows that the increased use of ICT does not necessarily improve the learning outcomes if primary teachers are not trained well enough to use digital tools in pedagogically efficient ways.

A second significant finding is that those students who are especially strongly favourable for using digital tools have slightly different views of mathematics and the importance of mathematics than those students who are not so strongly for using ICT in preprimary mathematics education. They seem to prefer more entertaining and less structured methods in mathematics education and, for them, the importance of mathematics in preprimary education is a little lower than for other students. We do not want to emphasize the practical significance of these differences but only mention our concern that increasing the use of ICT in preprimary mathematics education should not happen by decreasing the mathematical content or the quality of preprimary mathematical education. As Sarama's and Clements' (2009) survey suggests, digital tools can be used for improving the quality of preprimary mathematics education; the challenge is to develop appropriate pedagogical approaches. This requires that preschool teachers have a sufficient pedagogical content knowledge in mathematics, cf. Lee \& Ginsburg (2007) and Palmer \& Björklund (2016). Our findings show that the Swedish primary and preprimary student teachers are only modestly confident that this is the case, see Table 2 .

Perhaps, the most surprising finding in this study was that the students who are strongly favourable for using digital tools were also more favourable for taking more responsibility (from parents) for children's learning of those mathematical skills that they need in school. This result may tell about their personal qualities, e.g., that they are in general more open and willing to take responsibility and to try new things such as using digital tools. On the other hand, it is also possible that, since they perceive the importance of mathematics in preprimary education being lower than other students perceive, they also consider the challenge in taking the responsibility for children's mathematical education being smaller than other students. This issue would be an interesting topic for further research. 


\section{References}

Cross, C. T., Woods, T. A., Schweingruber, H. A. (2009). Mathematics learning in early childhood: paths toward excellence and equity. Washington: National Academies Press. On line [20.3.2018] http://www.nap.edu/catalog/12519

Dovenburg, E., Samuelsson, I. P. (2011) Early mathematics in the preschool context. In N. Pramling, I. P. Samuelsson (Eds), Educational Encounters, Nordic Studies in Early Childhood Didactics, International Perspectives on Early Childhood Education and Development 4 (pp. 37-64), Dordrecht: Springer.

Grigutsch, S., Raatz, U., Törner, G. (1998). Einstellungen gegenüber Mathematik bei Mathematiklehrern. Journal für Mathematikdidaktik, Vol.19, pp.3-45.

Hill, H. C., Ball, D. L., Schilling, S. G. (2008). Unpacking pedagogical content knowledge: conceptualizing and measuring teachers' topic-specific knowledge of students. Journal for Research in Mathematics Education, Vol.39, pp.373-400.

Lee, J. S., Ginsburg, H. P. (2007). What is appropriate mathematics education for fouryear-olds? Pre-kindergarten teachers' beliefs. Journal of Early Childhood Research, Vol.5, pp.2-31.

Mertala, P. (2017). Wag the dog - The nature and foundations of preschool educators' positive ICT pedagogical beliefs. Computers in Human Behavior, Vol.69, pp.197-206.

Mit. (2018). Digital tools for the classroom. On line [15.3.2018] https://openlearning.mit.edu/campus/digital-tools-classroom

Palmér, H., Björklund, C. (2016). Different perspectives on possible-desirable-plausible learning in preschool. Nordic Studies in Mathematics Education, Vol.21, pp.177-191.

Sarama, J., Clements, D. H. (2016). "Concrete" computer manipulatives in mathematics education. Child Development Perspectives. 2009, Vol. 3, pp. 145-150.

Skolverket. Läroplan för förskolan Lpfö 98. Reviderad. Stockholm: Skolverket, 2016. On line [20.3.2018] https://www.skolverket.se/laroplaner-amnen-och-kurser

Tossavainen, T., Hirsto, L. (2018). Tablet computers and Finnish primary and lower secondary students' motivation mathematics. To appear in E. Norén \& H. Palmer (Eds.), NORMA17 Proceedings (pp. xx-xx). Linköping: SMDF.

Tossavainen, T., Viholainen, A., Asikainen, M., Hirvonen, P. (2017). Explorations of Finnish mathematics students' beliefs about the nature of mathematics. Far East Journal of Mathematics Education. Vol.17, pp.105-120.

Wang, X. C., Hoot, J. L. (2006). Information and communication technology in early childhood education. Early Education and Development, Vol.17, pp.317-322. ISSN 10409289.

Wilson, M., Cooney, T. (2002). Mathematics teacher change and developments. In G. C. Leder, E. Pehkonen, G. Törner (Eds.), Beliefs: A hidden variable in mathematics education? (pp. 127-147). Dordrecht: Springer.

Yelland, N. (2005). The future is now: A review of the literature on the use of computers in early childhood education (1994-2004). AACE Journal, Vol.13, pp.201-232. 